\title{
LATÉNSKE HRADISKO V STUPNOM ${ }^{1}$
}

\author{
Lucia Ježišková - Karol Pieta
}

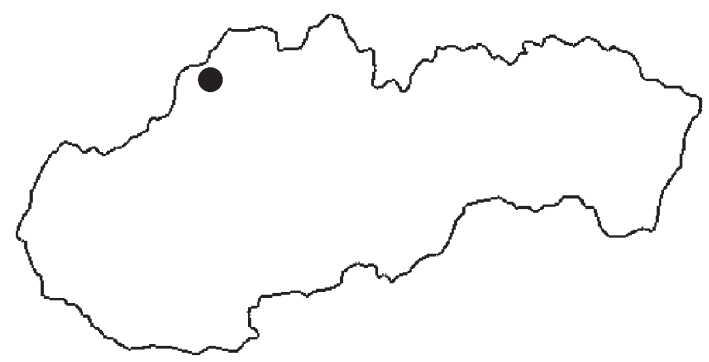

DOI: https://doi.org/10.31577/szausav.2019.65.5

Key words: hillfort, Slovakia, Early LaTène, ritual axe, Púchov culture, hoards of gold coins and earrings.

\section{The LaTène Hillfort in Stupné}

Find contexts of two hoards of golden coins from the end of the LaTène period were expertly documented at the hillfort in the densely populated Váh river region in northwestern Slovakia and knowldege of topography and settlement at the site was obtained. A ritual axe is evidence of activities in the Early LaTène period.

\section{ÚVOD}

Vrch Žeravica (525 m n. m.) leží severne od obce Stupné, okr. Považská Bystrica (obr. 1). Lokalitu v minulosti pravdepodobne objavil Š. Meliš, ktorý z vrchu uvádza keramiku púchovskej kultúry a zo včasného stredoveku. V katastri obce ešte spomína lužické, púchovské a včasnostredoveké sídlisko v polohe Duhé medzi Stupným a Jasenicou (Meliš 2008). Názov Žeravica nesie aj d’alšia južnejšie situovaná lokalita na rozhraní chotárov Stupné a Udiča-Prosné, s osídlením z neskorej doby bronzovej a doby laténskej (Májsky 2002, 85).

Stupné-Žeravica je zalesnený vápencový hrebeň, vybiehajúci od severovýchodu do Papradnianskej doliny (obr. 2). Z južnej a východnej strany chránia prístup na vrchol strmé skalné galérie.

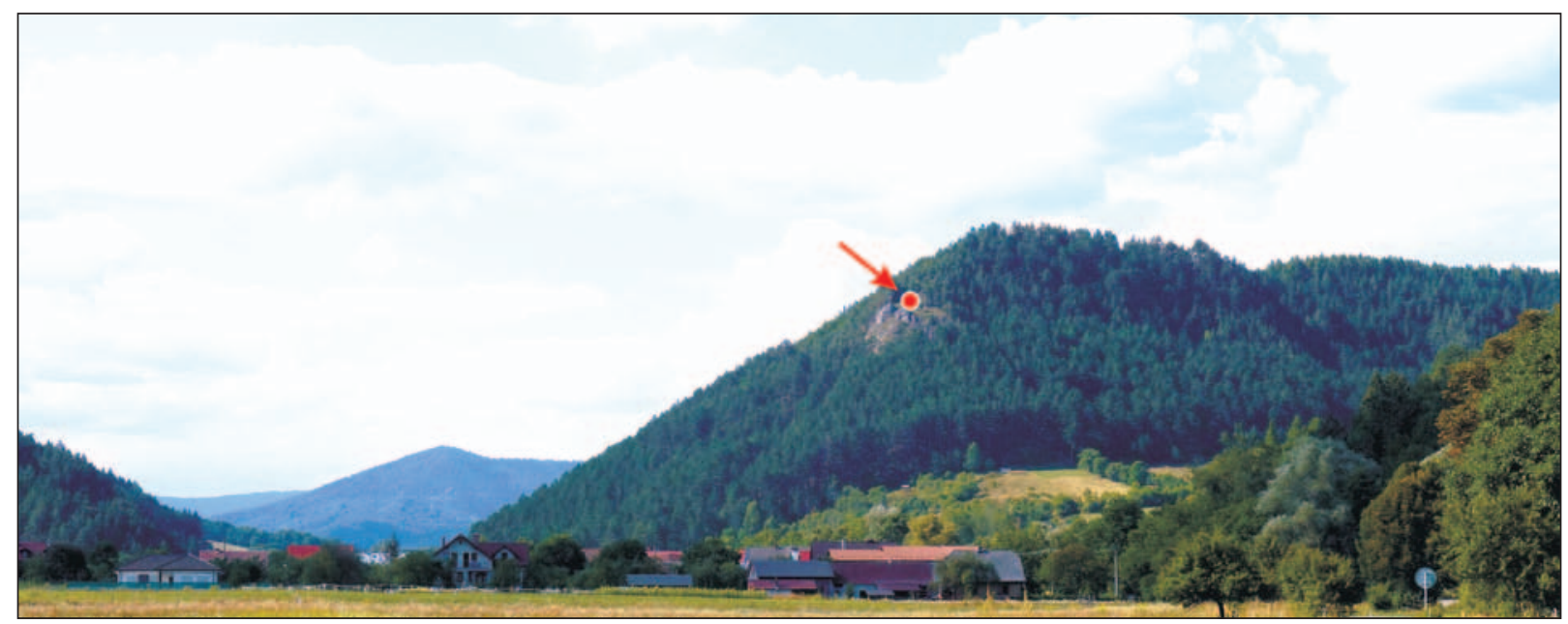

Obr. 1. Stupné-Žeravica. Pohlad na lokalitu od východu.

1 Práca vznikla v rámci grantového projektu agentúry VEGA 2/0001/18 „Slovensko a stredné Podunajsko: vývoj od včasnej doby dejinnej po začiatok stredoveku“ a projektu APVV-14-0842 „Stredná Európa medzi keltskými oppidami a staroslovanskými centrami“. 


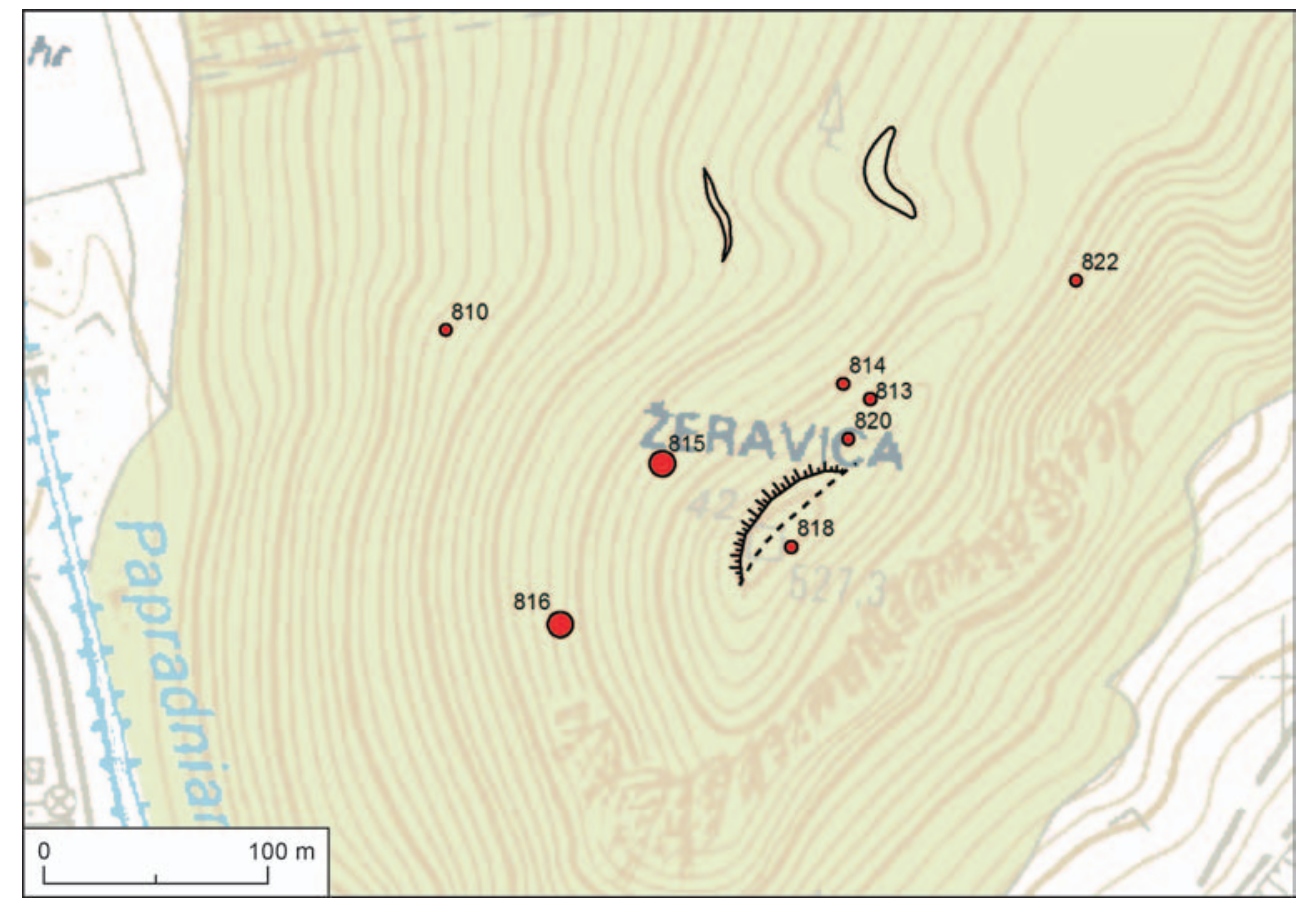

Obr. 2. Stupné-Žeravica. Mapa hradiska s vyznačením dvoch terás v severnej časti areálu a opevnenia na vrchole. Ć́slované body vyznačujú miesta depotov (väčšie značky) a významnejších nálezov v okolí opevnenia. Bod (GPS) 810 - železná zápona; 813 - zoomorfný závesok; 814 - minca typu Zemplín; 815 - depot 1; 816 - depot 2; 818 - minca typu Nitra; 820-822 - minca typu Divinka.

Aj na západnej strane je svah mimoriadne strmý. Vrchol tvorí extrémne úzky skalnatý hrebeň, na západnej až severozápadnej strane rozšírený o umelú terasu. Ide bezpochyby o jednoduché zemné opevnenie, azda spojené s radom obydlí. Vrchol s terasou je pomerne dobre prístupný od severu po hrebeni, ktoré predeluje výrazné sedlo. Toto dôležité miesto je $\mathrm{z}$ doliny od potoka Papradnianka (s prevýšením takmer 200 m) smerom od západu dostupné bočnou dolinou, cez ktorú cez dve umelé terasy vedie cesta. Serpentínový chodník je v súčasnosti prebudovaný na krížovú cestu, s ukončením v spomenutom sedle. Podla povrchových nálezov keramiky a ojedinelých drobných predmetov sa na terasách nachádzala osada k vrcholovej fortifikácii. Potvrdzuje to aj hákovitá opasková zápona, ktorá bola objavená pri terénnych úpravách 7. zastavenia kalvárie (obr. 2: 810) a hrot železného oštepu zo spodnej sídliskovej terasy (obr. 7: 1).

Po roku 2000 sa na hradisko Žeravica sústredila neželaná pozornost̉ hladačov, ktorí tu objavili množstvo významných nálezov. Čast’ cenných artefaktov z lokality sa podarilo zhromaždit a uverejnit (Fröhlich 2016). Predmety, ktoré sa v roku 2010 dostali do Archeologického ústavu SAV a do Trenčianskeho múzea sú vyhodnotené $\mathrm{v}$ tomto príspevku. V roku 2017 autori príspevku v spolupráci s miestnymi obyvatel'mi vykonali podrobnú obhliadku, dokumentáciu a zameranie lokality. Identifikovali hlavné prvky terénu a zemného opevnenia a podla zachovalých výkopov i údajov zo zameraní GIS sa podarilo určit polohu niektorých nálezov a najmä miesto uloženia dvoch depotov.

\section{MINCE}

Na svahoch vrchu sa okrem spomenutých dvoch hromadných nálezov našli aj ojedinelé mince. Minca typu Divinka bola na strmom východnom svahu, asi $30 \mathrm{~m}$ pod hrebeňom (obr. 2: 822). Razba typu Nitra (obr. 3: 1) pochádza z východného svahu, asi $8 \mathrm{~m}$ pod vrcholovým hrebeňom. Drobná minca typu Zemplín (obr. 3: 2) bola objavená na svahu severne od opevnenia (obr. 2: 814). Zdokumentovat' sa podarilo aj jeden mušlový a jeden lopatkovitý statér, uchovávané v súkromnej zbierke (obr. 3: 3, 4). Nevieme však, či boli nájdené samostatne, alebo boli súčastou niektorého z identifikovaných depotov. Spomenuté 


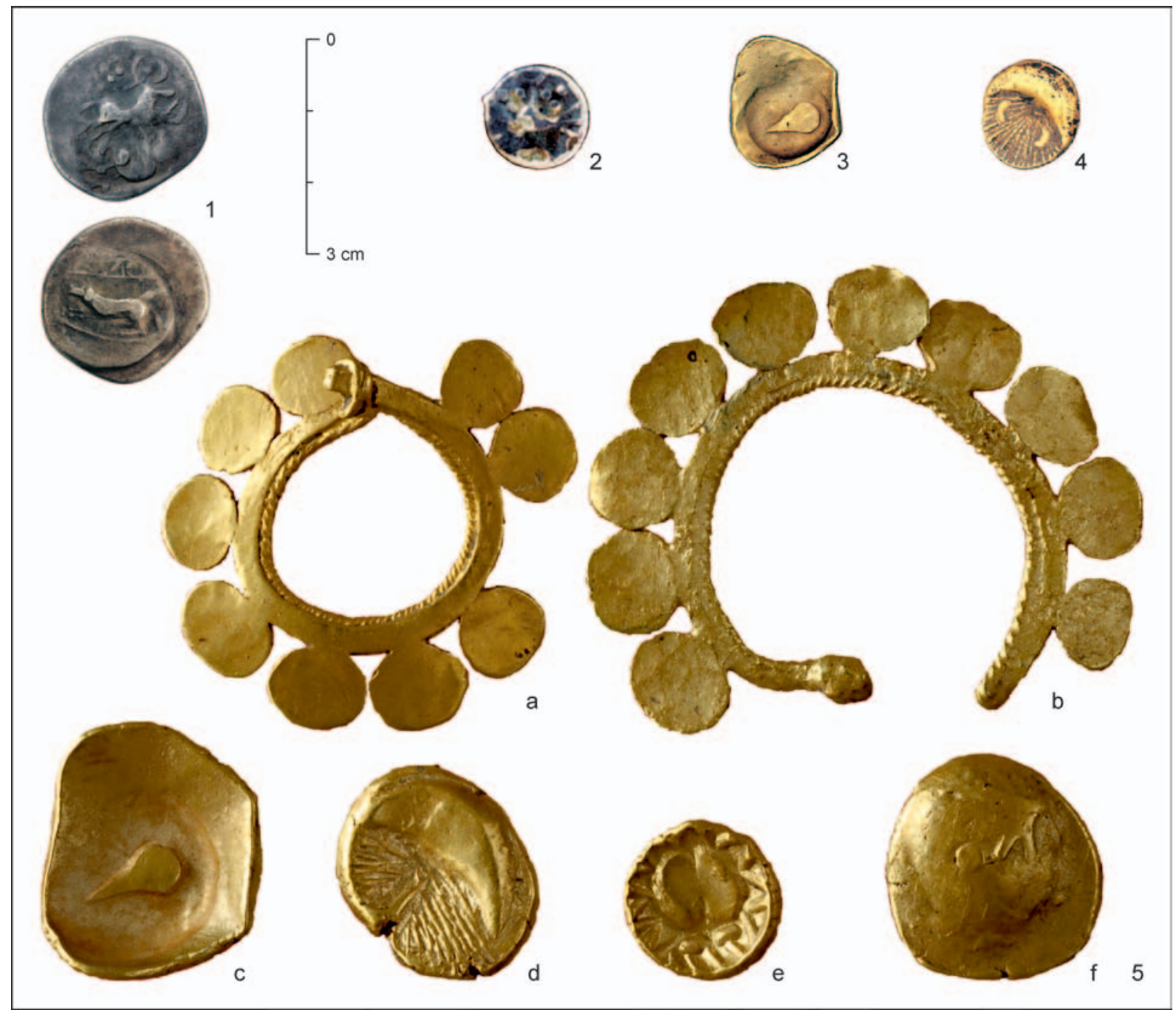

Obr. 3. Stupné-Žeravica. 1-4 - mince nájdené na svahoch vrchu; 5 - depot 1 (podla J. Fröhlicha 2016). 2-5 - bez mierky.

spektrum mincí dobre zodpovedá nálezovému prostrediu severozápadnej časti púchovského územia, kde sa najmä typy Divinka a Nitra koncentrujú. Na niektorom z väčších stredísk tohto regiónu sa aj predpokladá ich razba (Kolníková 2003). Upozorňujeme na exemplár typu Nitra, na ktorom je vidiet’ stopy po sekundárnom prerazení z mince vel'kobystereckého typu. Ide o d’alší kus dokumentujúci takýto nezvyčajný postup, ktorý zrejme súvisel s nedostatkom mincového kovu v tejto oblasti na konci doby laténskej (Kolníková 1973; 1984; 2013, 15, 16; 2015).

\section{Depot 1}

Na strmom západnom svahu, asi 45 metrov pod valom, sa v kamennom závale pod koreňmi vel'kého smreka v híbke asi $40 \mathrm{~cm}$ našli štyri zlaté mince a dve náušnice z rovnakého kovu (obr. 2: 815; 3: 5a-f; podrobný popis a rozbor nálezov pozri Fröhlich 2016).

\section{Depot 2}

Na strmom juhozápadnom svahu pod valom (obr. 2: 816) sa podla overeného zdroja našiel poklad zlatých mincí, ktoré pozostávali z neznámeho počtu mušlových statérov a lopatkovitých razieb. Súčasti 


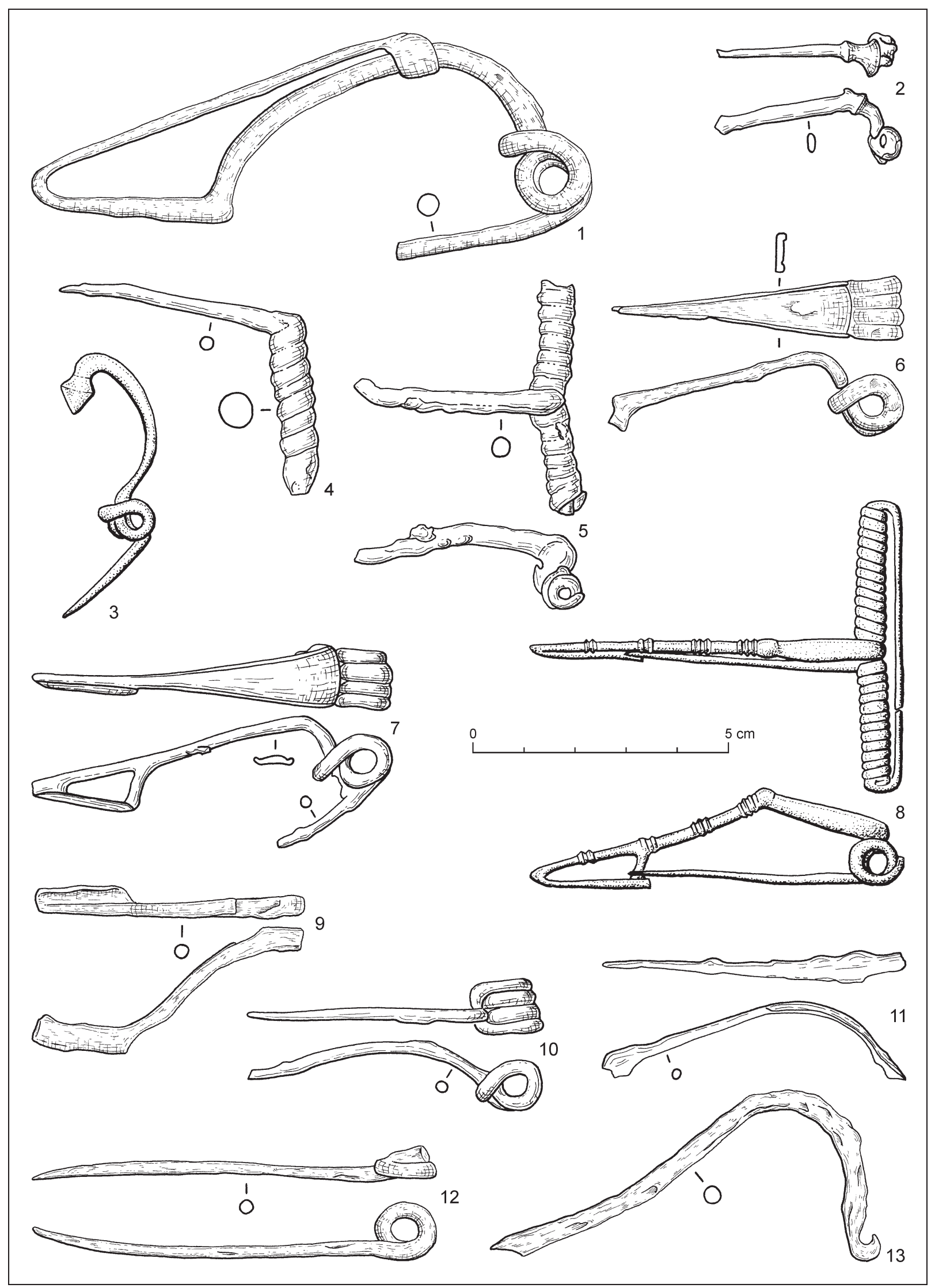

Obr. 4. Stupné-Žeravica. Spony z hradiska a zo svahov pod ním. 1-5, 7-13-železo; 3, 8 - bronz. 


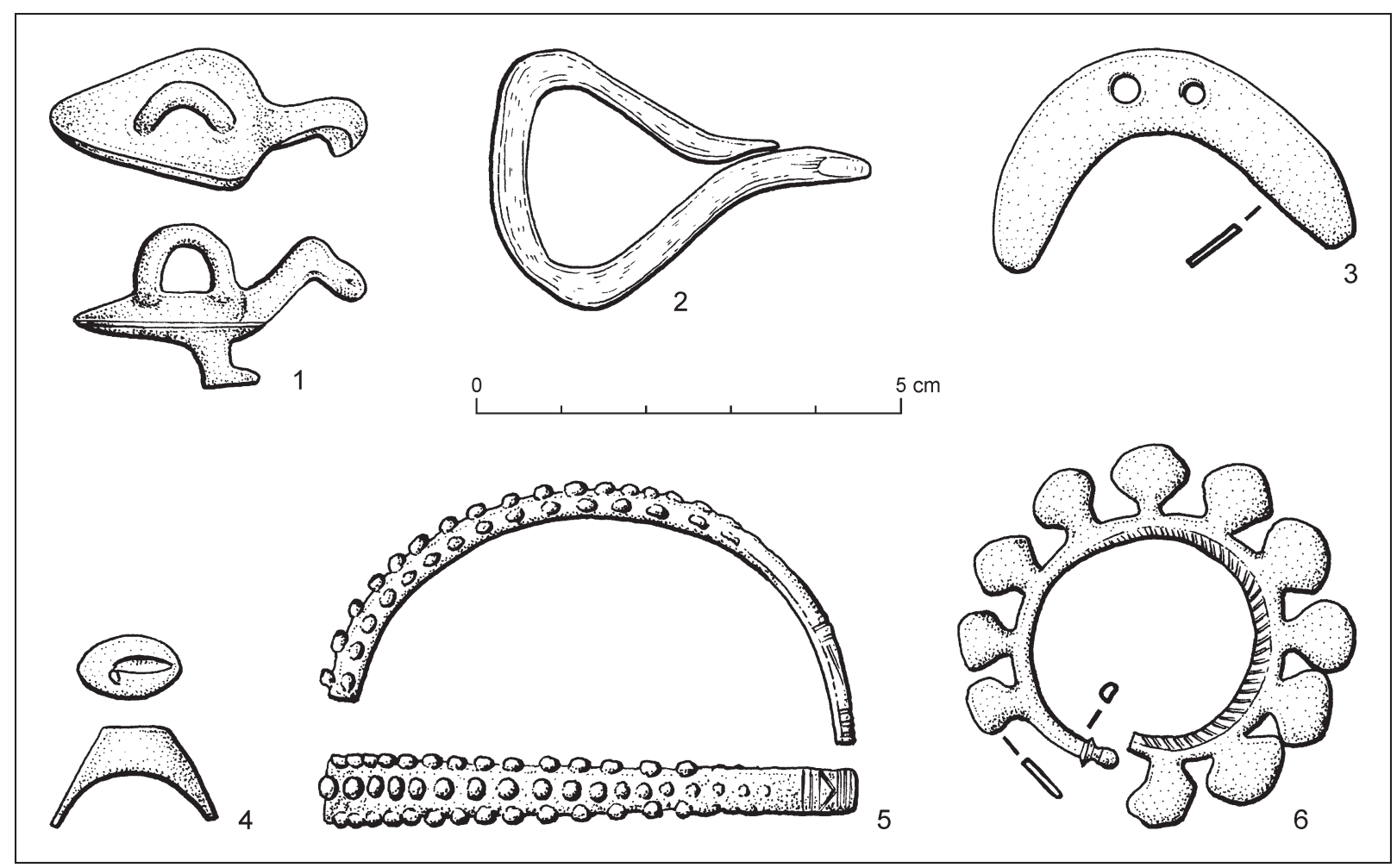

Obr. 5. Stupné-Žeravica. Ozdoby a súčasti opaska. 1, 3-6-bronz; 2 - železo.

nálezu boli rozptýlené dolu svahom na ploche asi 150 × $80 \mathrm{~cm}$. Na mieste nálezu, ktoré sa nachádza južne od depotu 1 sa vraj dodatočne podarilo nájst štyri d’alšie statéry.

Nálezisko i zhromaždené či získané predmety majú mimoriadny charakter. Preto si zaslúžia podrobnejšie spracovanie a zverejnenie spresnených údajov. V nasledujúcom texte hodnotíme drobné predmety, ktoré boli autorom k dispozícii a dokázatelne sa našli na lokalite. Samostatne sa vyjadríme k publikovaným nálezom, ktoré zhromaždil a spracoval J. Fröhlich. ${ }^{2}$ Mince budú vyhodnotené na inom mieste.

\section{Popis nálezov (výber)}

Spona hladkej spojenej konštrukcie s mierne asymetrickým lúčikom kruhového prierezu, so štvorzávitovým vinutím a vnútornou tetivou. Pätka je pripevnená svorkou v dvoch tretinách lúčika. Dlžka 109 mm. Železo (obr. 4: 1).

Fragment spony blízkej typu A65 s náznakom uzlíka a trojuholníkovitou hlavicou. Dížka fragmentu $35 \mathrm{~mm}$. Železo (obr. 4: 2).

Fragment spony s prehnutým lúčikom typu A 18 s uzlíkom a štvorzávitovým vinutím s vnútornou tetivou. Zachovalá dížka fragmentu $37 \mathrm{~mm}$. Bronz (obr. 4: 3).

Ihla a čast’ dlhého vinutia s deviatimi závitmi spony spojenej konštrukcie. Dížka zachovaného vinutia $36 \mathrm{~mm}$, dížka ihly $49 \mathrm{~mm}$. Železo (obr. 4: 4).

Fragment spony spojenej konštrukcie s dlhým štrnásṫzávitovým vinutím na stredovej oske a plochým lúčikom. Dížka vinutia $45 \mathrm{~mm}$, zachovalá dížka lúčika $42 \mathrm{~mm}$. Železo (obr. 4: 5).

Oblúkovitá spona s pásikovým lúčikom a poškodeným rámcovým zachycovačom. Vinutie s vnútornou tetivou je štvorzávitové. Ihla chýba. Zachovaná dížka 59 mm. Železo (obr. 4: 6).

Oblúkovitá spona s pásikovým lúčikom, plynule sa zužujúcim do pätky s rámcovým zachycovačom. Ihla sa zachovala len sčasti. Štvorzávitové vinutie má vnútornú tetivu. Dížka 70 mm. Železo (obr. 4: 7)

Spona s lomeným lúčikom, tromi naznačenými uzlíkmi a rámcovým zachycovačom, dlhým vinutím s 2 x 13 závitmi. Bronz (obr. 4: 8).

Fragment prednej časti lúčika a čast’ plného zachycovača spony. Zachovaná dížka 54 mm. Železo (obr. 4: 9).

Fragment spony pravdepodobne spojenej konštrukcie s nízkym oblúkovitým lúčikom a štvorzávitovým vinutím s vnútornou tetivou. Dížka fragmentu 56 mm, šírka vinutia $10 \mathrm{~mm}$. Železo (obr. 4: 10).

2 Jemu patrí naša vd’aka za ochotu dat k dispozícii text svojho príspevku ešte pred publikovaním, ako aj za možnost použit originálnu fotografickú dokumentáciu v tejto štúdii. 


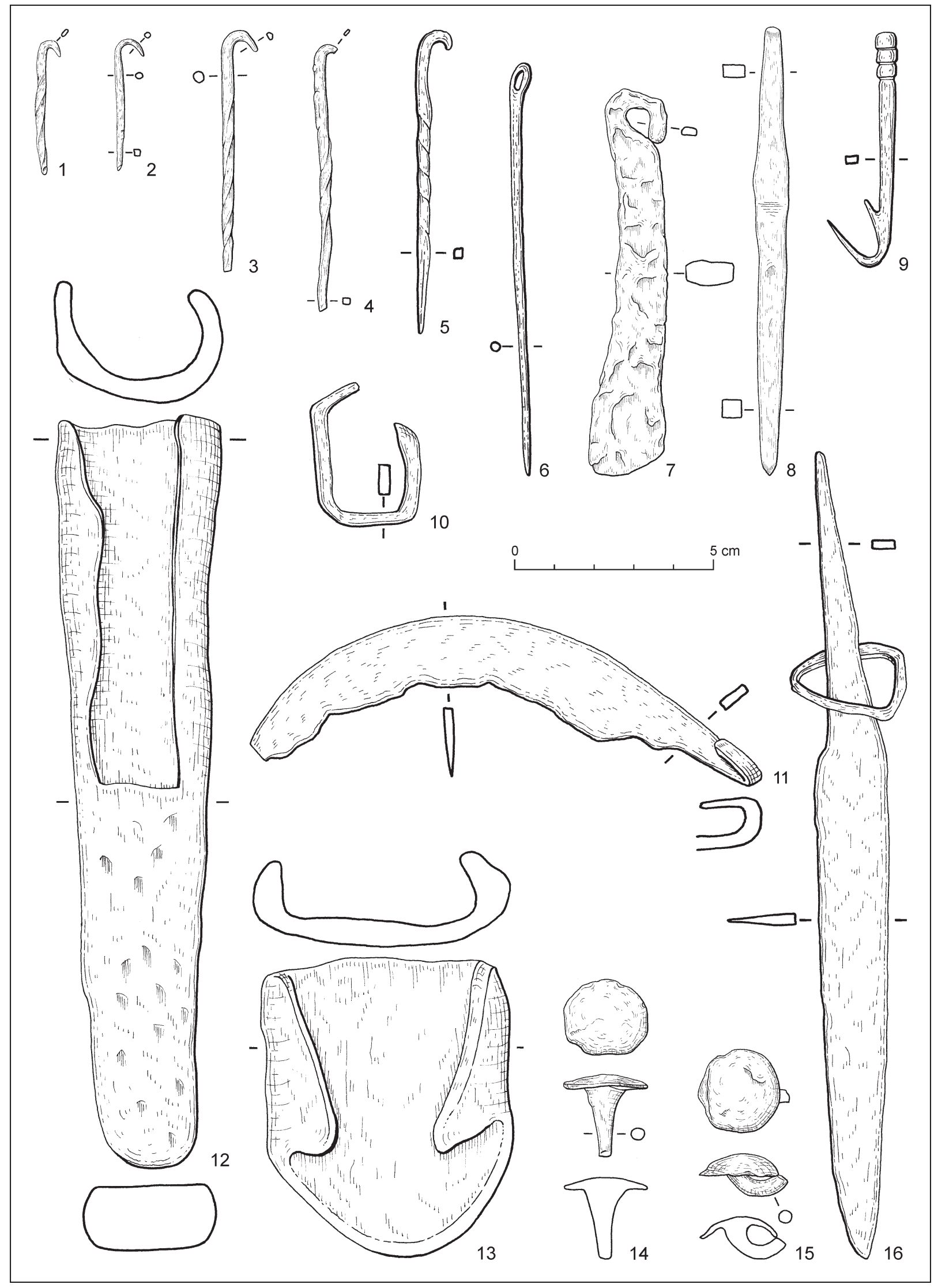

Obr. 6. Stupné-Žeravica. Železné predmety. 


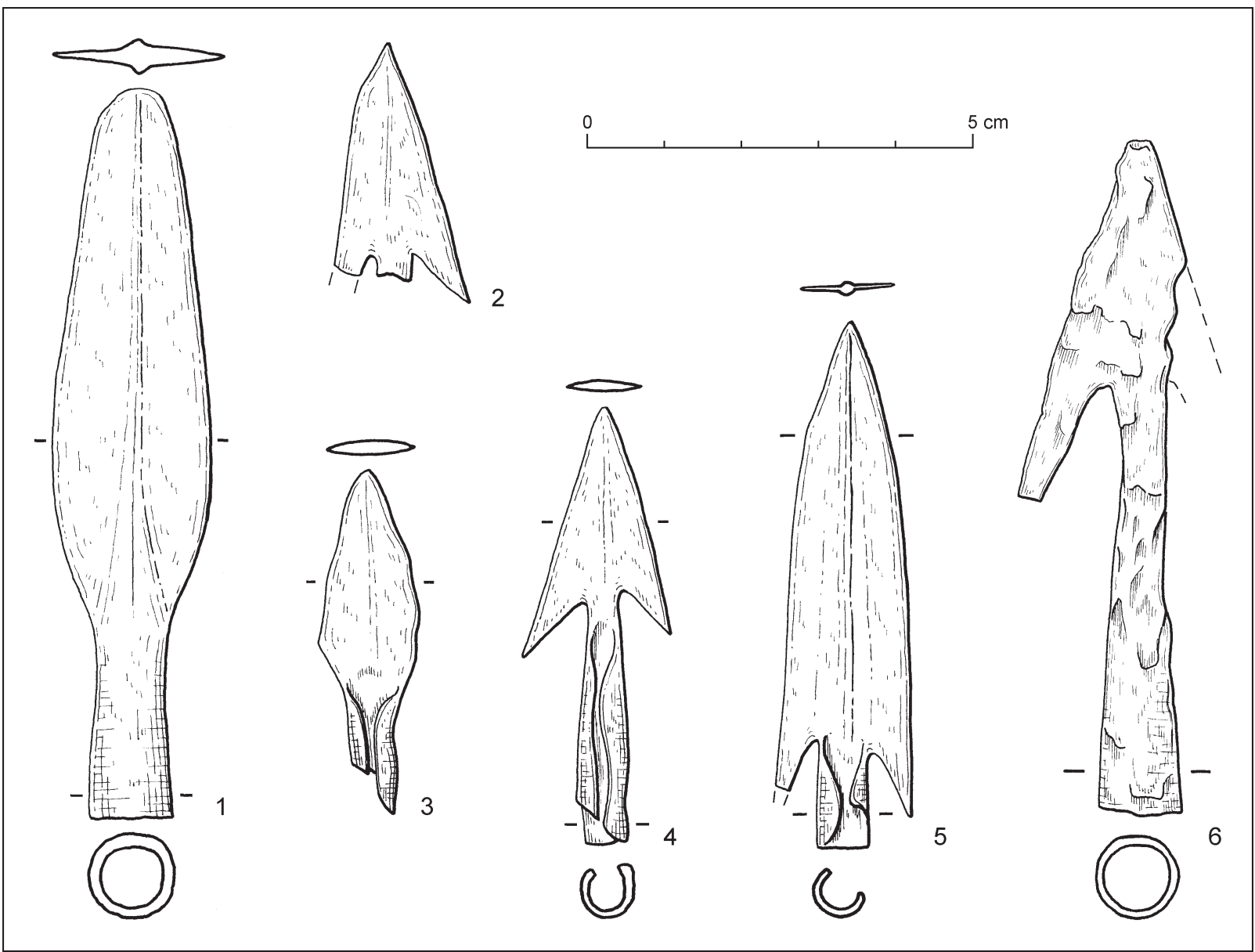

Obr. 7. Stupné-Žeravica. Hroty oštepu a šípov. Železo.

Fragment spony s oblúkovitým, v zadnej časti splošteným lúčikom, s pravdepodobne plným zachycovačom. Dížka fragmentu $61 \mathrm{~mm}$. Železo (obr. 4: 11).

Ihla a čast’ vinutia spony. Zachovaná dížka $79 \mathrm{~mm}$. Železo (obr. 4: 12).

Fragment spony s prehnutým lúčikom kruhovitého prierezu. Zachycovač, vinutie a ihla chýbajú. Železo (obr. 4: 13).

Závesok v tvare vtáka so závesným uškom. Dížka 34 mm. Bronz (obr. 5: 1).

Zápona s trojuholníkovým rámikom z tyčinky oválneho prierezu. Háčik chýba. Zachovalá dížka 30 mm. Železo (obr. 5: 2).

Lunicovitý plechový závesok v tvare polmesiaca, s dvomi otvormi na zavesenie. Šírka 43 mm (obr. 5: 3).

Prsteň s kuželovitým zosilnením pre očko, ktoré sa nedochovalo. Väčšia čast’ pásikovej obrúčky chýba. Bronz. Šírka fragmentu $16 \mathrm{~mm}$ (obr. 5: 4).

Náramok oválneho prierezu so zúženými koncami, zdobenými ryhami. Povrch je zdobený tromi radmi hráškovitých náliatkov. Časṫ. Predpokladaný vnútorný priemer $58 \mathrm{~mm}$, maximálny prierez $9 \mathrm{~mm}$. Bronz (obr. 5: 5).

Náušnica s lupeňovými výbežkami po obvode otvoreného kruhu, zdobeného šikmými ryhami. Vonkajší priemer 47 mm. Bronz (obr. 5: 6).

Ociel'ka s trapézovite rozšírenou platničkou ukončenou závesným očkom. Dížka 95 mm, šírka 12/20 mm. Železo (obr. 6: 7).

V zhromaždenom súbore je okrem laténskej keramiky aj náradie - háčkovky (obr. 6: 1-5), priebojník (obr. 6: 8), rybársky háčik (obr. 6: 9), kosák (obr. 6: 11), radlica/kopáč (obr. 6: 12), hroty oštepu a šípov (obr. 7: 1-6), ako aj 3 zliatky bronzu.

\section{VYHODNOTENIE NÁLEZOV}

Vel'ká väčšina položiek, získaných pri prieskume alebo odovzdaných v preverených materiáloch patrí do včasnohistorického obdobia. Výnimkou je bronzová lod'kovitá spona, ktorú vo svojej štúdii vyobrazuje J. Fröhlich. Ide o typ Šmarjeta s poškodenou a zrejme dodatočne skrátenou nôžkou. 


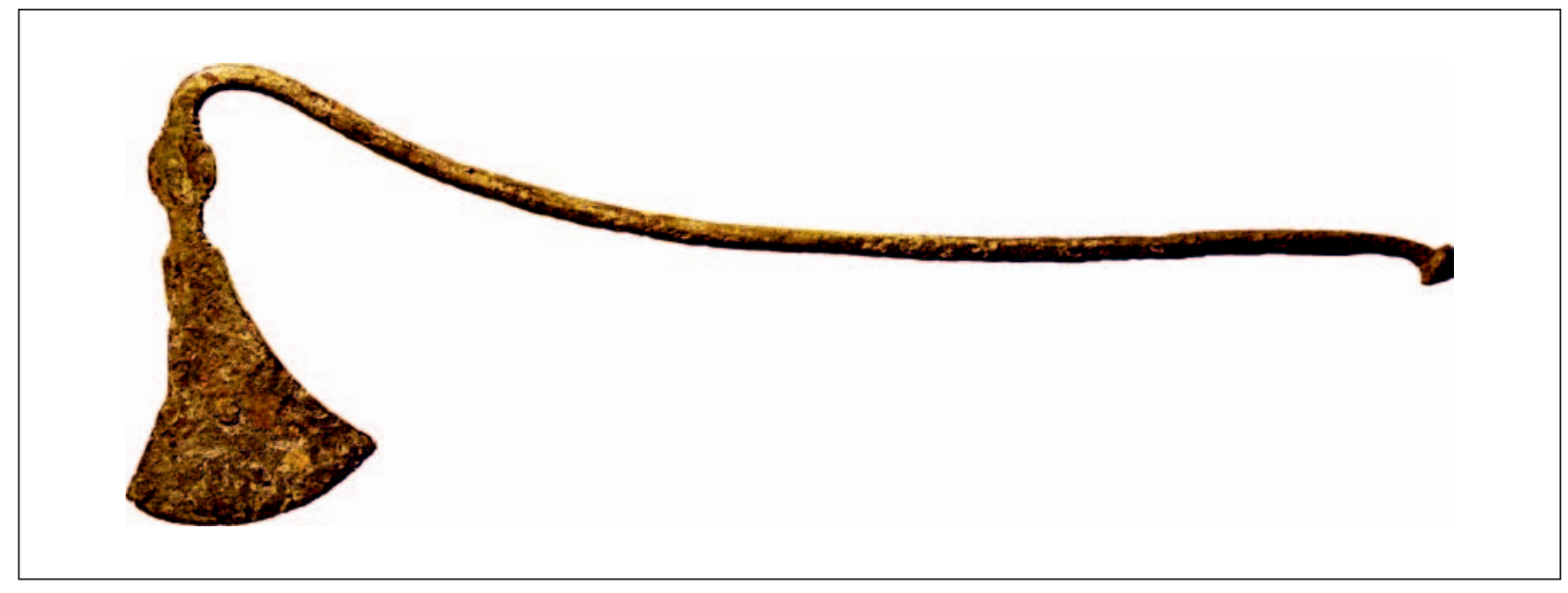

Obr. 8. Stupné-Žeravica. Celokovová sekera. Železo (podl’a J. Fröhlicha 2016). Bez mierky.

Na území pôvodnej lužickej kultúry ide o jeden z mála nálezov (Benediková 2017, 346; Jakubčinová 2008, obr. 1: 14; Pieta/Veliačik 2014, 18, s lit.). Počas prieskumu sa na lokalite žiadne súdobé nálezy nezistili.

\section{Železná sekera}

Celokovová plochá železná sekera, uverejnená ako nález zo študovaného náleziska (obr. 8; Fröhlich 2016, obr. 11), je štvrtým exemplárom tohto typu zo Slovenska. Všetky doterajšie kusy podobného tvaru i rozmerov pochádzajú zo známeho hradiska Slepý vrch v Horných Orešanoch a jednoznačne patria do včasnolaténskeho obdobia. Sekera zo Stupného tu má priliehavú analógiu (Pieta 2014a, obr. 3: 3). Rovnaké datovanie majú aj napodobneniny týchto rituálnych predmetov - bronzové závesky v tvare sekerky s typickým prehnutím rukoväte, vejárovým ostrím a naznačenou ludskou tvárou v tylovej časti, nájdené v detských hroboch na pohrebisku Dürrnberg bei Hallein (Pauli 1975, obr. 3: 28; 5: 9; pozri tiež Spehr 2005, 67, obr. 14: 11-13, 20). Otázne pravdaže zostáva, ako dlho sa tvary takýchto symbolických nástrojov používali. Podla súčasného stavu poznania ich však treba spájat’ s včasnou dobou laténskou.

\section{Artefakt l'udskej hlavy}

Problémovým nálezom je další publikovaný artefakt zo Stupného, poškodený fragment z cínovej zliatiny, zobrazujúci ludskú hlavu (obr. 9). Po formálnej stránke rámcovo zapadá do včasnolaténskeho výtvarného štýlu. Tvár má mandlové oči, ryhovaním naznačené vlasy a zahnutý nos. Zhora i zdola je orámovaná volútami, pripomínajúcimi nákrčník. Podobné kompozičné riešenie s olemovaním tváre a s umiestnením kruhového útvaru (,oka") nad čelom nachádzame na jednej zo železných sekier z Horných Orešian i na spone zo Slovenského Pravna. Problematické sú však detaily stvárnenia a najmä použitý materiál zo zmesi cínu a olova $(80,77$ \% Cn, 16,9 \% Pb, 2,77 \% Cu: Fröhlich 2016), ktorý je v našom prostredí celkom nezvyčajný a vyvoláva pochybnosti o pôvode a veku predmetu.

Podobný artefakt sa našiel $\mathrm{v}$ Nimnici na hradisku Holíš (obr. 10). Je to značne opotrebovaný fragment prsteňa, ktorý bol sekundárne

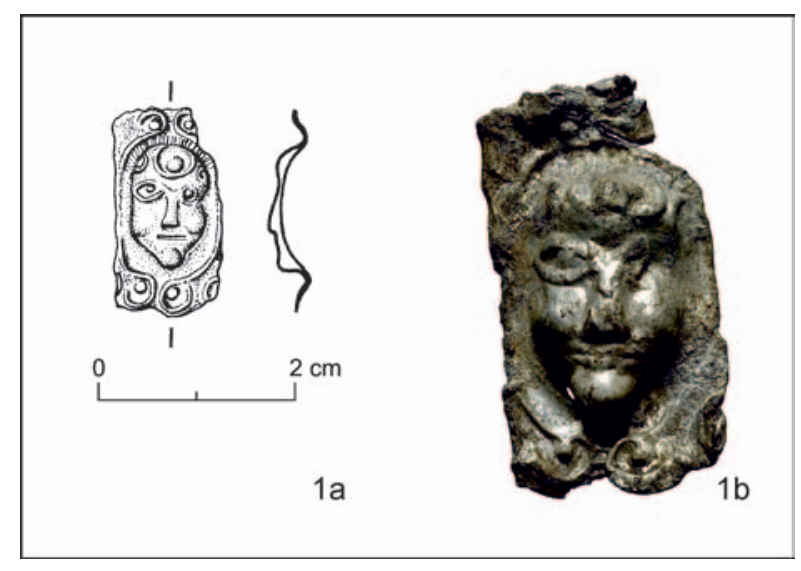

Obr. 9. Stupné-Žeravica. Fragment cínového predmetu s vyobrazením ludskej tváre. $1 \mathrm{~b}$ - bez mierky. 


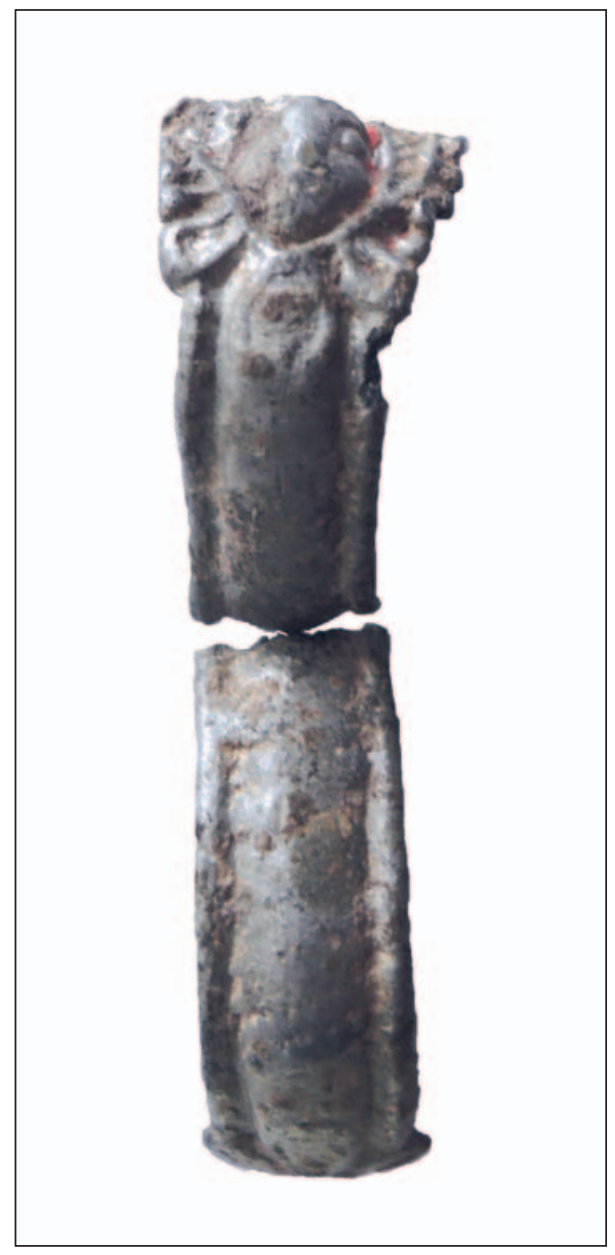

Obr. 10. Nimnica-Holíš. Čast’ cínového prsteňa. Bez mierky. upravený do podoby krúžku či prívesku. Obvodová pásovina v tvare $\mathrm{D}$ má po oboch stranách zosilnené lišty. V pôvodne centrálnej rozšírenej a ozdobne upravenej časti je reliéfne zobrazená maska s okrúhlymi očami, masívnym nosom a hrotitou vystúpenou bradou, ktorá pripomína včasnolaténske vzory. V obvodových priehlbniach lemujúcich tvár vidiet’ stopy červeného farbiva. Použitým materiálom $(59,93 / 66,30 \% \mathrm{Sn}, 37,05 / 30,99 \% \mathrm{~Pb}, 2,46 / 2,14 \% \mathrm{Fe})$ i celkovým prevedením sa artefakt podobá na vyššie opísaný nález zo Stupného, taktiež vyrobený z cínovo-olovenej zliatiny. Je zrejmé, že v oboch prípadoch ide o recentné artefakty, zatial' bez analógií. Iné halštatské a včasnolaténske predmety $\mathrm{v}$ súbore overeného materiálu $\mathrm{z}$ polohy Stupné-Žeravica zatial' chýbajú. S ohl'adom na existenciu d’alšej polohy rovnakého mena zostáva príslušnost’ týchto predmetov $\mathrm{k}$ našej lokalite otvorená. V našom prostredí sú nezvyčajné aj obe strieborné, snád' macedónsko-thrácke mince, publikované ako nálezy zo Stupného (Fröhlich 2016, obr. 13; 14).

Ociel'ka s plochým trapézovitým telom a závesným očkom (obr. 6: 7) naznačuje sporadické aktivity na Žeravici aj 2.-4. stor. po Kr. Ociel'ky tohto typu sú rozšírené najmä v przeworskej kultúre, ale vyskytujú sa aj na okolitých územiach včítane púchovskej kultúry doby rímskej (von Carnap-Bornheim 2002, s lit. Istvánovics/Kulcsár 2017).

Vrch Žeravica bol osídlený aj vo včasnom stredoveku. Okrem noža (obr. 6: 16) to potvrdzuje krátka radlička so širokou roztvorenou tulajou (obr. 6: 13), ktorá má početné analógie v depotoch i medzi vel'komoravskými sídliskovými nálezmi. Prítomnost' včasnostredovekého osídlenia na lokalite Stupné-Žeravica potvrdzujú aj nálezy ojedinelých črepov i zmienka Š. Meliša o nálezoch slovanskej keramiky $\mathrm{s}$ viacnásobnou vlnovkou.

\section{Spony}

Pomerne vel'ká kolekcia neskorolaténskych nálezov z lokality napriek pochopitel'nej neistote pri verifikácii niektorých položiek je dôležitá pre poznanie púchovského osídlenia v tejto časti Považia. Časový rozsah využívania polohy spresňujú najmä spony.

Hladké spony spojenej konštrukcie sú bežným spínadlom mladšej a neskorej doby laténskej včítane púchovskej kultúry (obr. 4: 1). Ich datovanie sa nedá úzko vymedzitł. Sporadicky nastupujú už v stupni LTC2 a sú jedným z vedúcich typov stupňa LTD1 (Pieta 1982, 22). V hromadnom náleze vo Folkušovej-Necpaloch sa tento typ vyskytol ešte so včasnorímskymi sponami A 236c (Pieta 2014b, 135).

Oblúkovité spony s pásikovým lúčikom so štvorzávitovým vinutím, vnútornou tetivou a plným alebo rámcovým zachycovačom (obr. 4: 6, 7) boli na severe Slovenska značne rozšírené. Uplatnili sa tu hlavne ich jednoduchšie železné varianty s plochým alebo mierne klenutým lúčikom. Tento typ spôn sa však vyskytuje aj na západnom Slovensku (Horné Orešany: Pieta 2014a, obr. 3: 11), ako aj v oblasti s dáckym osídlením. Patria k typickým produktom stupňa LTD1. Ich konštrukcia vychádza z nauheimských spôn (Typ 5a: Feugère 1985, 203; Pieta 2000a, 141). Sú však nezdobené, majú väčšie rozmery a boli zhotovované prevažne zo železa. Nevylučujeme, že ich typologickým pokračovaním sú niektoré varianty lyžicovitých spôn (Pieta 2014b, 135).

Spony s dlhým vinutím (obr. 4: 4,5) boli oblúbené najmä na strednom Považí. V centrálnej časti púchovskej kultúry a na severnom Slovensku sú zriedkavé (Pieta 2014b, 135). Sú to jednodielne spony, zhotovené väčšinou z tenkého bronzového alebo železného drôtu. Lúčik má plochý či poloblúkový tvar a nôžka je k lúčiku pripevnená svorkou tesne nad vinutím, zriedkavejšie v strede lúčika. Niekedy sa ešte 
objavuje náznak uzlíka. Dlhé vinutie so stredovou oskou má 14-20 závitov a vonkajšiu tetivu. Spony je možné zaradit do vyznievania stredolaténskeho stupňa LTC a do stupňa LTD1. Zriedkavo mohli prežívat' do stupňa LTD2 (Pieta 1982, 25, 26).

Spona s lomeným lúčikom (obr. 4: 8) je hybridným typom. V duchu mladších stredolaténskych spôn spojenej konštrukcie má lúčik členený plastickými uzlíkmi a dlhé vinutie. V rámci okruhu blízkeho sponám A65 bola odlievaná. Je blízka východoalpským spínadlám typu Magdalenska Gora (Dizdar/Božič 2010) alebo typu Oberleiserberg (Karwowwski/Militký 2011). Varianty týchto spôn, severne od Dunaja, zrejme predstavujú stopy norických vplyvov v domácom keltskom prostredí (Bratislava-Devín: Pietal Zachar 1993, obr. 115: 8; Trenčianske Bohuslavice: Pieta 2010, obr. 16: 17 a d’alšie kusy), ale aj v prilahlej časti púchovskej kultúry (Stupné, Mikušovce). Blízkou analógiou k exempláru zo Stupného je bronzová spona zo Starého hradiska na Morave, patriaca k typu Magdalenska Gora, variant 8 (Dizdar/Božič 2010, 149; Meduna 1970, obr. 8: 13). Spony tohto okruhu patria k mladším formám neskorolaténskeho stupňa D1.

Spona Almgren 65 (?) sa zachovala vo fragmente (obr. 4: 2). Pravdepodobne patrí k lokálnym železným napodobneninám rozšírených liatych bronzových spínadiel, typických pre neskorolaténsky stupeň D1 (Danielisová/Militký 2014, 49, s lit.). V oblasti púchovskej kultúry sú tieto imitácie pomerne ojedinelé (Pieta 2010, obr. 12: 6).

Oblúkovité a prehnuté železné spony (obr. 4: 3, 13) sú typickým nálezom stupňa D2 (Pieta 2014b, 135, 136). Tento typ je vyrábaný z drôtu šošovkovitého alebo okrúhleho prierezu. V oblasti rozšírenia púchovskej kultúry sa stretávame hlavne s ich hladkými železnými derivátmi.

\section{Bronzový náramok}

Masívne otvorené náramky so zužujúcimi sa koncami a s rôznymi druhmi povrchovej výzdoby (obr. 5: 5) patria v púchovskej kultúre doby laténskej k bežným druhom ozdôb, ktorých tradícia, ale s inou povrchovou výzdobou, sa zrejme viaže na starší domáci vývoj (Benediková 2017, 358; Pieta 2012, 322, 323). Náramky s hráškovými náliatkami sú v tomto prostredí menej časté (Pieta 1982, tab. XII: 9), avšak výzdoba radov náliatkov sa bežne uplatňovala na d’alších druhoch ozdôb (závesky, náušnice).

\section{Náušnica typu Vel'ký Bysterec}

(obr. 5: 6)

Je typickým šperkom púchovskej kultúry. V Stupnom sú tieto okrasy zastúpené dvomi zlatými a jedným bronzovým exemplárom. Zlaté ozdoby z depotu 1 boli montované spájkovaním z viacerých častí. Oba kusy majú otvorený obvodový oblúk z tenkej pásoviny, ktorá bola v polovici dížky prehnutá a roztepaná. K oblúku bola zvnútra priletovaná tordovaná tyčinka alebo filigránový drôt, vonkajšok oblúka lemujú ploché lupienky, ktoré sú spojené z dvoch častí. Okrem eponymného náleziska (Čaplovič 1960) sa takáto zlatá náušnica našla aj na sídlisku v Divinke-Ohrádzi (Petrovský-Šichman 1965, 74, tab. X: 24; Pieta 2010, obr. F 21: 2). Z bronzu odlievané náušnice imitovali zlaté predlohy. Príkladom je exemplár, nájdený na západnom svahu Žeravice ned’aleko depotu 2 (obr. 5: 6; 11). Ďalšie kusy sa našli v Skalke nad Váhom a v Porúbke. Tento vo svojej dobe ojedinelý druh šperku prenikal aj za hranice púchovského osídlenia, a to v bronzovom vyhotovení (Trenčianske Bohuslavice: Pieta 2010, obr. 16: 11; Pobedim), ale aj zo zlata (Slatina nad Bebravou: Pieta, $v$ tlači). Podla svedectva hromadných nálezov sa neskorolaténske náušnice s obvodovými lupienkami vyskytovali ešte na počiatku doby rímskej. Ich príbuzným variantom sú menšie bronzové kusy zdobené hráškovitými náliatkami, ktoré sú známe najmä z Liptovskej Mary (Pieta 1982, 60-62, 1996, 91).

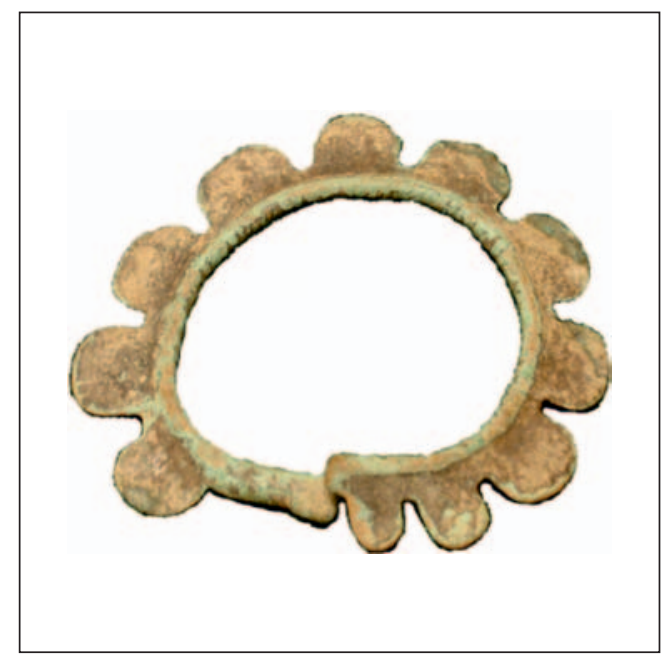

Obr. 11. Stupné-Žeravica. Náušnica. Bronz. Bez mierky. 


\section{Bronzový závesok}

(obr. 5: 1)

Zobrazuje pravdepodobne vodného vtáka. Drobné zoomorfné plastiky a závesky patria k častým nálezom v materiálnej kultúre mladolaténskej civilizácie i v púchovskej kultúre. Apotropajné závesky $\mathrm{s}$ uškom boli súčastou náhrdelníkov. Pomerne časté sú aj drobné plastiky so zvislým otvorom na upevnenie (Pieta 2010, obr. 137: 1, 2). Vtáčie a iné zoomorfné figúrky sa vyskytujú na sídliskách (Čižmář 2012, 150-152; Rudnicki 2014, 429), ale aj v hromadných nálezoch bronzových ozdôb, napr. v Udiči, Kolačne alebo v depote 10 v Plaveckom Podhradí (Pieta 2010, 216, 218). Zobrazovanie vodných vtákov ako symbolov slnka má ešte predkeltskú tradíciu (Green 1992). V neskorej dobe laténskej a na začiatku doby rímskej sa tento motív uplatňuje i ako aplikácia na ozdobách, napr. na pásových záponách.

\section{Prstene}

(obr. 5: 4)

Patria k najčastejšie dovážaným drobným predmetom na neskorolaténskych lokalitách, najmä na oppidách (Píc 1903, tab. VII: 4, 12, 14-34). Časté sú bronzové, ale i železné prstienky s oválnym skleneným očkom, prípadne s gemou alebo jej imitáciou, nepochybne antického pôvodu (Beckmann 1969). Našli sa na viacerých púchovských sídliskách (Blatnica, Liptovská Mara, Košeca-Nozdrovice, Nimnica, Stupné: Hrnčiarik 2013, 151; Pieta 2010, 119: 1-3).

\section{Zbrane}

V našom súbore sú zastúpené malým oštepom a hrotmi šípov (obr. 7). Oštep so strechovitým listom, krátkou tulajou a pravdepodobne pôvodne odlomeným a následne sekundárne skráteným a zaobleným hrotom sa nedá presne chronologicky zaradit', ale podobné hroty sa na neskorolaténskych lokalitách nachádzajú pomerne často. Šípy s listovitým alebo trojuholníkovým hrotom so spätnými háčikmi sa masovo vyskytujú na púchovských hrádkoch, najmä v ich zánikovej fáze na začiatku doby rímskej (Pieta 2005).

Hrot so zaobleným hrotom s otvorenou tulajou (obr. 6: 12) patrí do skupiny nástrojov neurčitého datovania, ktoré zrejme slúžili ako motyky či špicáky, prípadne ako okutie lahkého brázdiča (Pieta 2010, 236). Žatevné náradie zastupuje kosák s koncovým tŕňom na upevnenie rukoväte (obr. 6: 11). Patrí do skupiny malých exemplárov s relatívne širokou čepelou. Podobné kusy sa vyskytujú v stredo až neskorolaténskych súvislostiach, a to i v oblasti púchovskej kultúry (Penack 1993; Pieta 2010, 241, obr. 109: 12, 15).

\section{Železné zápony}

Železné zápony s jednoduchým trojuholníkovým alebo oválnym rámikom a krátkym háčikom (obr. 5: 2) boli bežnou súčastou odevu na rozsiahlom priestore strednej i západnej Európy od konca strednej doby laténskej, kedy sa vyvinuli zo zložitejších zapínaní laténskych kovových opaskov (Bataille 2001). Ako tradičný výrobok boli používané ešte začiatkom doby rímskej ako súčast̉ germánskeho odevu (Salač 2010,362). Ako nám to potvrdzujú hrobové nálezy z Bytče-Hrabového a z Mikušoviec, železné hákovité zápony preživajú cez prelom letopočtu aj v oblasti púchovskej kultúry.

Vrch Žeravica nad obcou Stupné patrí k dominantným miestam Papradnianskej doliny v pravobrežnej časti stredného Považia s hustým neskorolaténskym osídlením. Výskumné práce sa tu realizovali len $\mathrm{v}$ obmedzenom rozsahu a väčšina závažných nálezov bola získaná bez možnosti spol’ahlivého preverenia ich nálezových okolností. Preto zostávajú naše poznatky obmedzené na všeobecné úvahy, ktoré sa opierajú o vlastné nálezy a preverené informácie. Oba neskorolaténske zlaté poklady a včasnolaténska rituálna sekerka si zaslúžia komentár, ktorý má byt๋ doplnkom záslužnej publikácie J. Fröhlicha a príspevkom k jeho téze o existencii kultového miesta na tomto mieste.

Depoty zlatých i strieborných mincí a šperkov patria už dnes $\mathrm{k}$ pomerne bežným nálezom na mnohých púchovských lokalitách, najmä na hradiskách s doloženým zánikovým horizontom hradísk na počiatku doby rímskej. Tento fakt sa týka aj viacerých súdobých opevnení v bezprostrednom okolí Stupného 


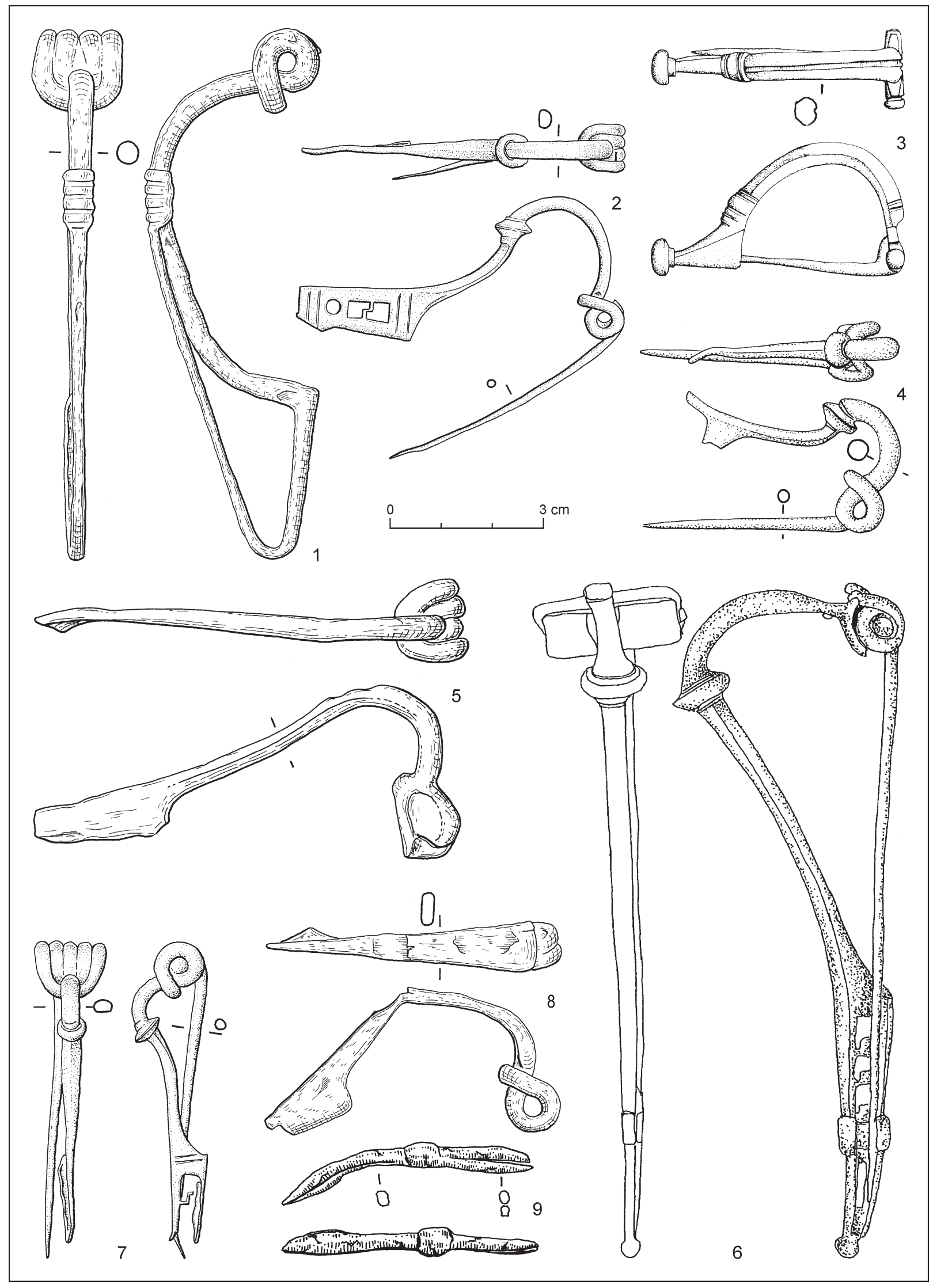

Obr. 12. Nimnica-Holíšs. Spony. 1, 5, 8, 9- železo; 2-4, 6, 7 - bronz. 


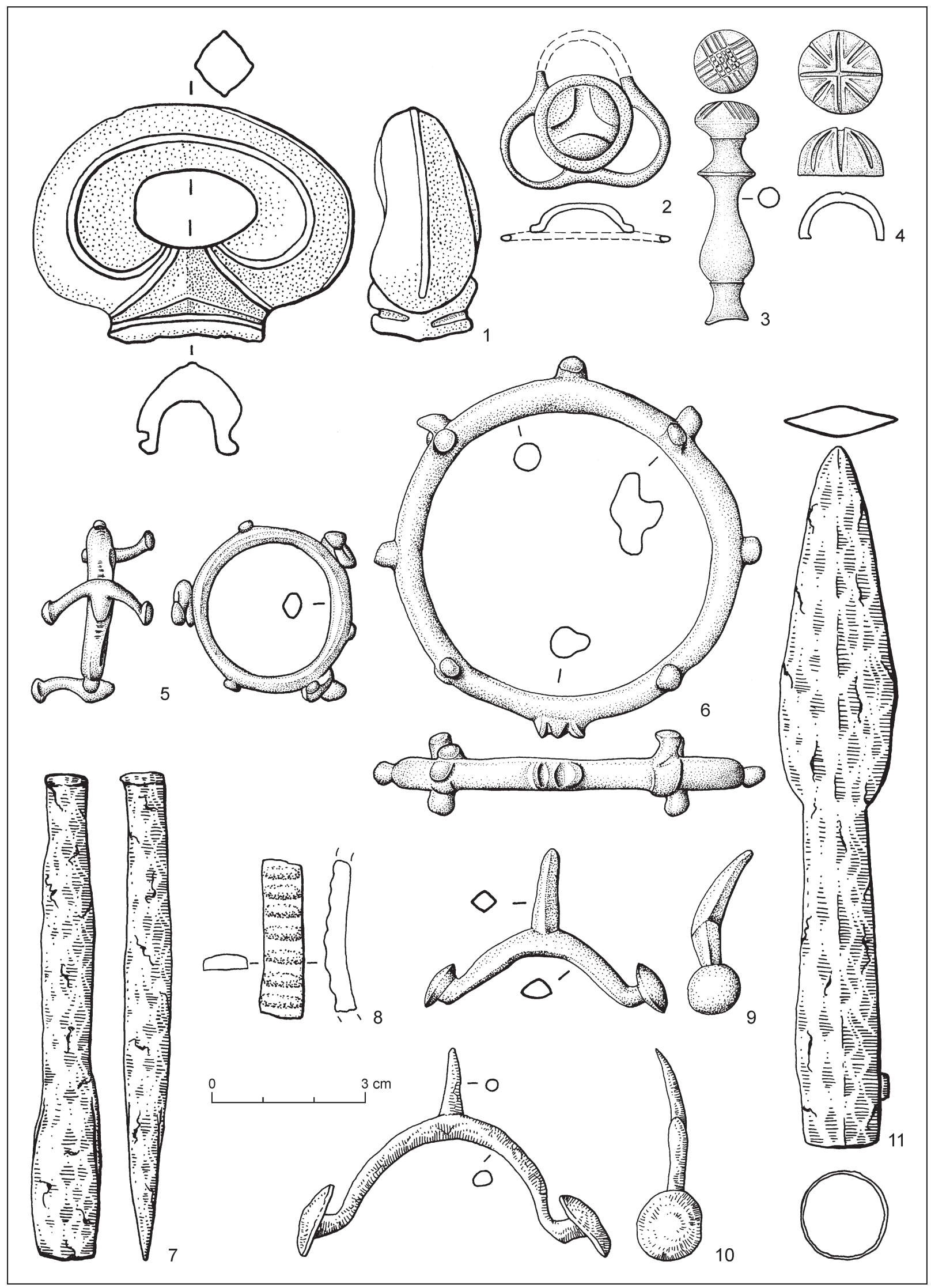

Obr. 13. Nimnica-Holíš. Nálezy z hradiska. 1, 5, 6, 8, 9- bronz; 2-4 - bronz a email; 7, 10, 11 - železo. 
(Udiča, Nimnica: Kolníková 2003, 232; Pieta 2010, 218). Ukladanie hromadných nálezov má viaceré možnosti a varianty výkladu. Uschovávanie hodnotných vecí v čase ohrozenia nie je jediným vysvetlením tohto javu, ktorý je v púchovskej kultúre a hlavne $\mathrm{v}$ spomenutom časovom horizonte obzvlášt častý. Je reálny predovšetkým $\mathrm{v}$ prípade početných požiarom zničených púchovských opevnení so spálenými obydliami a množstvom nálezového inventára včítane zbraní. Takisto výklad pokladov ako votívnych darov na hradiskách je iba jednou z možností pôvodného zámeru, ktorý zainteresovaní ludia sledovali a možno si predstavit aj kombináciu oboch zámerov v čase akútneho ohrozenia spoločenstva či jednotlivcov (Pieta 2010, 206-226).

$\mathrm{Z}$ prevereného súboru nálezov z lokality Stupné-Žeravica sa jasne vyčleňuje celokovová sekerka, patriaca do včasnolaténskeho obdobia (obr. 8). Ak je miesto nálezu určené správne (a nejde o nález zo spomenutej „druhej“ Žeravice), znamená to, že na nálezisku okrem bohato zastúpeného neskorolaténskeho horizontu existovali aj aktivity už niekde na konci 5. stor. pred Kr. (LTA). Kontinuita medzi obomi časovými úsekmi a ani predpokladaný včasnolaténsky horizont zatial nie sú doložené inými nálezmi.

Podla nálezového inventára bola poloha łažiskovo využívaná v neskorolaténskych stupňoch D1 a D2. V porovnaní s väčšinou púchovských hrádkov v našom súbore (zatial') chýbajú predmety zo stredolaténskeho obdobia, najmä zo stupňa $\mathrm{C} 2$, kedy sa púchovská sídlisková štruktúra na severnom a severozápadnom Slovensku formovala. V dostupnom súbore zatial’ chýba aj inventár včasnorímskej fázy B1a, typický pre spomenuté požiarom zničené opevnenia. Znova si však musíme pripomenút obmedzenú výpoved' materiálu z tejto lokality.

Na záver porovnajmenálezový súbor zo Stupného s dostupnými archeologickými prameňmi z výšinnej polohy Nimnica, Holíš (Holíž), okr. Púchov (obr. 12-14). Obe náleziská sú súčastou rozsiahlej koncentrácie osídlenia západne od stredného Váhu a sú od seba vzdialené približne $9 \mathrm{~km}$ vzdušnou čiarou. Aj v prípade hradiska Holís ide žial' o nálezisko, ktoré bolo odborne skúmané len v malom rozsahu (Moravčík 1976, 32-34; 1986, 162). Je známe značným počtom mimoriadnych nálezov, ktoré sú uložené vo verejných inštitúciách (Považské múzeum Žilina, Archeologický ústav SAV) a súkromných zbierkach. Keramika z lokality posúva začiatky osídlenia tejto strategickej polohy najmenej do staršej doby laténskej. Viaceré dobre zachovalé bronzové ozdoby s pseudofiligránovou výzdobou (z depotu ?) patria do stupňa LTC1 (Pieta 2010, F 2: 1; F 20). Tradične prevládajú nálezy zo staršieho stupňa púchovskej kultúry, s predpokladaným prerušením života na lokalite na začiatku doby rímskej. Popri štandardných prehnutých sponách (obr. 12: 4-6) si pozornost̉ zaslúži bronzová spona typu A 18a2 (obr. 12: 2; Demełz 1999, 122), ktorá bola v oblube najmä koncom posledného storočia pred Kr. V púchovskom prostredí zriedkavá spona typu Aucissa (obr. 12: 3; Riha 1994, typ 5.2.4) patrí k včasným formám s lúčikom kruhového prierezu, ktoré sa objavujú už v augustovskom období a vyskytujú sa počas celého prvého storočia po Kr., s jednoznačným tažiskom v jeho prvej polovici (Elschek 2014; Riha 1979, 115; 1994, 102, 106). Okrem iného sa tu našli aj amulety v podobe krúžkov a zvieracích plastík (obr. 13: 5, 6; 14), prsteň s gemou, viaceré solitérne mince včítane raritných drobných nominálov lopatkovitých mincí (Ručka 2012) a zatial nepublikovaný depot šiestich zlatých lopatkovitých mincí s hmotnostou od 5,33 po 5,50 g. Podla svedectva keramického materiálu (Moravč́k 1976, tab. XII: 11) bol kopec Holíš využitý (azda dočasne ako refúgium) aj v priebehu staršej doby rímskej.

\section{ZÁVER}

Nálezy zo Stupného, zhromaždené v tomto príspevku, spresnili chronologický rámec lokality. Bez rozsiahlejších terénnych prác tu môžeme len s určitou rezervou predpokladat prípadné kultové aktivity, ktoré naznačujú lokalizované depoty i starší včasnolaténsky artefakt, ktorý súvisí s rituálnymi 
praktikami. Profil náleziska Nimnica z tohto regiónu vykazuje viaceré spoločné znaky oboch hradísk: existenciu včasnolaténskeho horizontu (s určitými nálezmi blízkymi okruhu náboženských predstáv) a výrazný záverečný stupeň osídlenia s množstvom atraktívnych nálezov včítane mincí, amuletov a hromadných nálezov.

Obe náleziská, podobne ako aj iné výšinné polohy (Pieta 2014b) podporujú predstavu o využívaní týchto miest, ich blízkeho okolia, okrem bežného života a jeho ochrany aj k (príležitostným) rituálnym, obranným aktivitám, zrejme v súvislosti s dobou zániku púchovských opevnených sídiel. Tieto možno súviseli s kritickými fázami osídlenia krajiny na začiatku a na konci doby laténskej. Viac a naozaj objektívne potvrdených faktov môže priniest' len podrobnejší terénny výskum, pokial to dlhodobo poškodzované lokality ešte umožnia.

\section{LITERATÚRA}

Bataille 2001

Beckmann 1969

Benediková 2017

von Carnap-Bornheim 2002

Čaplovič 1960

Čižmář 2012

Danielisová/Militký 2014

Demetz 1999

Dizdar/Božič 2010

Elschek 2014

Feugère 1985

Fröhlich 2016

Green 1992

Hrnčiarik 2013

Istvánovics/Kulcsár 2017

Jakubčinová 2008

Karwowski/Militký 2011
G. Bataille: Les agrafes de ceinturon du sanctuaire de la Villeneuve-au-Catelot (Aube). Archäologisches Korrespondenzblatt 31, 2001, 443-460.

Ch. Beckmann: Metallfingerringe der römischen Kaiserzeit im freien Germanien. SaalburgJahrbuch 26, 1969, 5-106.

L. Benediková: Kulturkontakte des slowakischen Teils der Westkarpaten während der Hallstattzeit. In: E. Miroššayová/Ch. Pare/S. Stegmann-Rajtár (Hrsg.): Das nördliche Karpatenbecken in der Hallstattzeit. Wirtschaft, Handel und Kommunikation in früheisenzeitlichen Gesellschaften zwischen Ostalpen und Westpannonien. Budapest 2017, 335-381.

C. von Carnap-Bornheim: Der Trachtschmuck, die Gürtel und das Gürtelzubehöhr. In: J. Peška/J. Tejral: Das germanische Fürstengrab von Mušov in Mähren. Römisch-Germanischen Zentralmuseums Mainz, Monographiae 55. Mainz 2002, 189-305, 537-557.

P. Čaplovič: Púchovské sídlisko Trniny nad Vel'kým Bystercom. Slovenská archeológia 8, 1960, 186-187.

M. Čižmář: Nálezy drobné lidské a zvířecí plastiky z Moravy. In: G. Březinová/ V. Varsik (ed.): Archeológia na prahu histórie. K životnému jubileu Karola Pietu. Achaeologica Slovaca Monographiae, Communicationes Tomus XIV. Nitra 2012, 145-173.

A. Danielisová/J. Militký: Pozdně laténske spony z oppida Třísov získané povrchovou prospekcí v letech 2008-2013. Archeologické rozhledy 66, 2014, 40-66.

S. Demetz: Fibeln der Spätlatène- und Frühen römischen Kaiserzeit in der Alpenlädern. Frühgeschichtlichen und provinzialrömische Archäologie. Materialen und Froschungen 4. Rahden/Westfahlen 1999.

M. Dizdar/D. Božič: O nekim oblicima fibula s kasnolatenskog naselja Virovitica Kiškorija sjever. Prilozi Instituta za arheologiju u Zagrebu 27, 2010, 145-160.

K. Elschek: Ein frühgermanisches Grubenhaus mit Aucissa-Fibel und ein augusteischer As mit Kontermarke des VARUS aus Zohor (Westslowakei). Beitrag zur Ankunft der ersten Germanen und Römer in den Mitteldonauraum. Zborník SNM 108. Archeológia 24, 2014, 303-312.

M. Feugère: Les fibules en Gaule meridionale de la conquête à la fin du Ve d. ap. J.-C. Paris 1985.

J. Fröhlich: Poklad keltských šperkov a mincí z kultového miesta na kopci Žeravica pri obci Stupné na Slovensku. Folia numismatica, Supplementum ad Acta Musei Moraviae 30, 2016, 3-27.

M. Green: Animals in celtic life and myth. London - New York 1992.

E. Hrnčiarik: Römisches Kulturgut in der Slowakei. Herstellung, Funktion und Export römischer Manifakturerzeugnisse aus den Provinzen in der Slowakei. Teil 1. Universitätsforschungen zur prähistorischen Archäologie Band 222. Bonn 2013.

E. Istvánovics/V. Kulcsár: Once more about Sarmatian and Germanic connections - from a new point of view. In: B. Valentin Eriksen/A. Abegg-Wigg/R. Bleile/ U. Ickerodt (ed.): Interaktion ohne Grenzen. Beispiele archäologischer Forschungen am Beginn des 21. Jahrhunderts. Schleswig 2017, 387-397.

M. Jakubčinová: Ojedinelé nálezy z vrchu Marhát. Študijné zvesti AÚ SAV 44, 2008, 51-63.

M. Karwowski/J. Militký: The Oberleiserberg types in the context of Taurisci influeces. In: M. Guštin/M. Jevtić (ed.): The Eastern Celts. The Communities between the Alps and the Black Sea. Koper - Beograd 2011, 131-136. 
Kolníková 1973

Kolníková 1984

Kolníková 2003

Kolníková 2013

Kolníková 2015

Májsky 2002

Meliš 2008

Meduna 1970

Moravčík 1976

Moravčík 1986

Pauli 1975

Penack 1993

Petrovský-Šichman 1965

Pieta 1996

Pieta 1982

Pieta $2000 a$

Pieta 2005

Pieta 2010

Pieta 2012

Pieta $2014 a$

Pieta $2014 b$

Pieta 2018

Pieta/Veliačik 2014

Pieta/Zachar 1993

Píč 1903

Riha 1979

Riha 1994

Ručka 2012
E. Kolníková: Ku keltským minciam tzv. nitrianskeho typu. In: R. Radoměrský (ed.): Karel Castelin. Sborník př́spěvků k oslavě jeho životního díla, sestavený u př́ležitosti jeho 70. narozenin. Hradec Králové 1973, 13-21.

E. Kolníková: Beitrag zur Problematik des ostkeltischen Münzwesens. In: G. Grasmann/W. Janssen/M. Brandt (ed.): Keltische Numismatik und Archaeologie. Veröffentlichung der Referate des Kolloquiums keltische Numismatik vom 4. bis 8. Februar 1981 in Würzburg 1. BAR International Series 200, 1984, 166-184.

E. Kolníková: Fundmünzen in den laténezeitlichen Burgenwällen und anderen Höhenlagen in der Slowakei. Slovenská archeológia 51, 2003, 232, 233.

E. Kolníková: Keltská razba mincí na Slovensku a jej surovinové zdroje. In: Baníctvo a mincovníctvo v dejinách Slovenska. Kremnica 2013, 7-23.

E. Kolníková: Münzprägung und Geldwirtschaft an der Ostgrenze der boischen Besiedlung - Forschung sergebnisse und Fragestellungen. In: V. Salač/S. Sievers (ed.): Boier zwischen Realität und Fiktion. Akten des internationalen Kolloquiums in Český Krumlov vom 14.-16. 11. 2013. Bonn 2015, 253-271.

R. Májsky: Zberové nálezy zo stredného Považia. AVANS 2002, 2003, 84-86.

Š. Meliš: Výber statí o archeológii. Stredné Považie. In: M. Olšovský (ed.): Po stopách predkov. Archeológia stredného Považia od praveku po stredovek. Považská Bystrica 2008.

J. Meduna: Das keltische Oppidum Staré hradisko in Mähren. Germania 48, 1970, 34-59.

J. Moravčík: Ojedinelé archeologické nálezy v oblasti SZ Slovenska. Vlastivedný zborník Považia 12, 1976, 5-49.

J. Moravčík: Nálezy z Lednice, Púchova-Nimnice a Varína. AVANS 1985, 1986, 161, 162. L. Pauli: Keltischer Volksglaube. Amulette und Sonderbestattungen am Dürrnberg bei Hallein und im eisenzeitlichen Mittelauropa. Münchner Beiträge zur Vor- und Frühgeschichte 28. München 1975.

J. Penack: Die eisernen eisenzeitlichen Erntegeräte im freien Germanien. B.A.R. International series 583. Oxford 1993.

A. Petrovský-Šichman: Severozápadné Slovensko v dobe laténskej a rímskej. Vlastivedný zborník Považia 7, 1965, 53-129.

K. Pieta: Liptovská Mara. Včasnohistorické centrum severného Slovenska. Archeologické pamätníky Slovenska 5. Bratislava 1996.

K. Pieta: Die Púchov-Kultur. Studia Archaeologica Slovaca Instituti Archaeologici Academiae Scientiarum Slovacae 1. Nitra 1982.

K. Pieta: Die Siedlung Liptovská Mara II und die Anfänge der Einflüsse der Latène-Kultur im Westkarpatenraum. Slovenská archeológia 48, 2000, 315-346.

K. Pieta: Spätlatènezeitliche Waffen und Ausrüstung im nördlichen Teil des Karpatenbeckens. Slovenská archeológia 52, 2005, 35-79.

K. Pieta: Keltische Besiedlung der Slowakei. Jüngere Latènezeit. Archeologica Slovaca Monographiae Studia, Tomus XII. Nitra 2010.

K. Pieta: Bronzové náramky s vývalkami z konca doby halštatskej a začiatku doby laténskej na severnom Slovensku. In: Václav Furmánek a doba bronzová. Zborník k sedemdesiatym narodeninám. Nitra 2012, 315-324.

K. Pieta: Rituelle Beile aus dem Frühlatène Burgwall in Horné Orešany. In: J. Čižmářová/N. Venclová/G. Březinová (ed.): Moravské križovatky. Střední Podunají mezi pravěkem a historií. Brno 2014, 717-726.

K. Pieta: Hradiská vo Folkušovej-Necpaloch a Blatnici. Juhovýchodné prvky v púchovskej kultúre. Slovenská archeológia 62, 2014, 125-165.

K. Pieta: Ein mittellatènezeitlicher Brandopferplatz in Slatina nad Bebravou. Žiarové obetisko zo strednej doby laténskej v Slatine nad Bebravou. Študijné zvesti AÚ SAV 64, 2018, 89-114.

K. Pieta/L. Veliačik: Pozoruhodné depoty zo Sklabinského Podzámku. Studia Archaeologica Brunensia 19, 2014, 5-25.

K. Pieta/L. Zachar: Mladšia doba železná (laténska). In: T. Štefanovičová a kol. (ed.): Najstaršie dejiny Bratislavy. Bratislava 1993, 143-209.

J. L. Píč: Starožitnosti země České. II/2. Čechy na úsvitě dějin. Hradiště u Stradonic jako historické Marobudum. Praha 1903.

E. Riha: Die römischen Fibeln aus Augst und Kaiseraugst. Forschungen in Augst 3. Augst 1979.

E. Riha: Die römischen Fibeln aus Augst und Kaiseraugst. Die Neufunde seit 1975. Forschungen in Augst 18. Augst 1994.

M. Ručka: Nový typ keltských mincí ze středního Pováží - drobné nominály lopatkovitých statérů kmene Kotinů. Folia numismatica 26, 2012, 55-61. 
Rudnicki 2014

Salač 2010

Spehr 2005
A. Rudnicki: Nowa Cerekwia - the Middle La Tène centre of power north of the Carpathians. In: J. Čižmářová/N. Venclová/G. Březinová (ed.): Moravské križovatky. Střední Podunaji mezi pravěkem a historií. Brno 2014, 421-436.

V. Salač: K rozsahu a významu tzv. keltského dědictví v hospodářství starší doby římské v Čechách a ve střední Evropě. In: J. Beljak/G. Březinová/V. Varsik (ed.): Archeológia barbarov 2009. Hospodárstvo Germánov. Nitra 2010, 351-370.

R. Spehr: Rituell verbogene Waffen von der Steinsburg. Alt-Thüringen. Jahresschrift für Archäologie 38, 2005, 67-99.

\section{The LaTène Hillfort in Stupné}

\author{
Lucia Ježišková - Ka rol Pieta
}

Unwanted attention of illegal searchers was focused on the late LaTène hillfort of Stupné, Žeravica site, in the densely populated Váh river basin in northwestern Slovakia (Fig. 1; 2), after 2000. The submitted text assesses miniature artifacts obtained during surveys in 2010-2017 which arrived in the Institute of Archaeology of SAS and the Museum of Trenčín. The study comments on the finds which were collected and processed by J. Fröhlich (2016), including a hoard of golden earrings and coins (Fig. 3: 5a-f). In 2017, the find of the second hoard of golden coins (hoard 2) was additionally confirmed. It comprised an unknown number of shell-shaped staters and shovel-shaped mints. Parts of the find were according to a verified source - scattered down the hill over an area of approx. $150 \times 80 \mathrm{~cm}$. Besides, individual coins were also discovered types of Nitra, Zemplín (Fig. 3: 1, 2) and Divinka. As for the documented shell-shaped and shovelshaped staters, (currently in a private collection), we do not know whether they were discovered in one of the hoards or individually (Fig. 3: 3, 4).

The obtained collection of fibulae (Fig. 4) represents the period of stages LT C2 and LT D2. The use of the site mainly in the late LaTène period is obvious also from the finds of decorations. An open bronze bracelet (Fig. 5: 5) belongs to common ornaments of the LaTène phase of the Púchov culture. Earrings of Vel'ký Bysterec type are a typical jewel of the Púchov culture. Two golden earrings come from the hillfort in Stupné (Hoard 1; Fröhlich 2016) as well as one earring made from bronze (Fig. 5: 6, 10). This kind of jewel which was unique in that period expanded outside the Púchov settlement borders, more frequently as a bronze product (Trenčianske Bohuslavice: Pieta 2010, obr. 16: 11, Pobedim), sometimes made from gold (Slatina nad Bebravou: Pieta 2018, Abb. 16).

Weapons are represented in our collection by a spear (Fig. 7: 1) and arrow points (Fig. 7: 2-5). The spear with a roofshaped leaf and short socket cannot be exactly chronologically classified, however, similar arrow points are rather common at late LaTène sites. Arrows with leaf-shaped or triangular points and with grabbing hooks are frequent at Púchov fortifications, especially in their extinction phase in the beginning of the Roman period.

Besides the two above mentioned hoards of coins, individual coins of Divinka and Nitra types and a small mint of Zemplín type were discovered on the slope of Stupné hill. We were able to document one shell-shaped stater kept in a private collection. Nevertheless, we do not know whether it had been found alone or it used to be part of some of the identified hoards. The above mentioned scale of coins is well corresponding with the environment of the northwestern part of the Púchov area, where mainly Divinka and Nitra types are concentrated. Traces of secondary mining of the Vel'ký Bysterec type coin are visible on the exemplar of Nitra type.

Sporadical activities in the $2^{\text {nd }}-4^{\text {th }}$ centuries AD are suggested by a whetstone with a flat trapezoidal body and a suspension loop (Fig. 6: 7). Presence of early medieval settlement at the site of Stupné-Žeravica is confirmend by finds of rare sherds, a knife (Fig. 5: 16) and a short ploughshare with a wide open socket (Fig. 5: 13) which has numerous analogies in hoards and among settlement finds of Great Moravia.

Bronze boat-shaped fibulae of Šmarjeta type are a problem group of finds from the hillfort. It is described by J. Fröhlich in his study. It belongs to unique finds in the territory of the Lusatian culture (Hubina-Marhát: Jakubčinová 2008, obr. 1: 14; Sklabinský Podzámok: Pieta/Veliačik 2014, 18, with bibliography). A fully metallic flat iron axe (Fig. 5; Fröhlich 2016, obr. 11) is the fourth exemplar of this type from Slovakia. All previous exemplars of similar shapes and sizes come from the well-known hillfort of Slepý vrch in Horné Orešany and definitely belong to the Early LaTène period. How the shapes of such symbolical tools were used remains a question. According to the current state of research, they should be associated with the Early LaTène period.

A fragment of tin alloy representing a human head (Fig. 9) is also a problematic find. Formally, it resembles some features of the Early LaTène artistic style. The used material comprising tin and lead, however, is disputable $(80.77 \%$ 
Sn, $16.9 \% \mathrm{~Pb}, 2.77 \% \mathrm{Cu}$ : Fröhlich 2016), since it is very unusual in our environment and raises doubts regarding the origin and age of the artifact. A similar artifact was found in Nimnica, Holís hillfort (Fig. 11). It is a fragment of a ring secondarily re-shaped into a ring or a pendant. The used material (59.93/66.30 \% Sn, 37.05/30.99 \% Pb, 2.46/2.14 \% Fe) and its design and execution are identical with the find from Stupné. It is possible that both items are recent artifacts, without analogies so far.

Other Hallstatt and Early LaTène artifacts in the collection of the verified fund of finds from the site of StupnéŽeravica are absent at the moment. If the location of find is identified correctly, activities existed at the site - besides the richly represented late LaTène horizon - also at the end of the $5^{\text {th }}$ century BC (LT A). Continuity between the two periods or the assumed Early LaTène horizon have not been confirmed by any other finds. With regard to the existence of another site with the same name (Žeravica) in the neighbouring cadastral municipality, the affiliation of these important artifacts to the analyzed site of Stupné remains open. Judging by the inventory of finds, the site was mainly used in the Late LaTène stages D1 and D2. In comparison with most of the small Púchov hillforts, our collection lacks so far - artifacts from the Middle LaTène period, maybe with the exception of stage C2, when the Púchov settlement structure was formed in the north and northwestern Slovakia.

The study compares the site of Stupné with the upland site of Nimnica-Holís (Holíž). Both sites are parts of a large concentration of settlement west of the Central Váh river and are approx. $9 \mathrm{~km}$ (air distance) from each other. Unfortunately, Holís is also a site which has been expertly studied only to a small extent (Moravč́k 1976, 32-34; $1986,162)$ and later, it was disturbed by treasure hunters. Several exceptional finds from the site are deposited in public institutions or in private collections. Artifacts from the earlier stage of the Púchov culture prevail (Fig. 12), with assumed interruption of life at the site in the beginning of the Roman period. There are also parts of horse harness as well as amulets in form of rings and animal figurines (Fig. 13: 1-6, 14), a ring with a gem and several solitaire coins including rare miniature nominals of shovel-shaped coins (Ručka 2012). A previously unpublished hoard of six golden shovel-shaped coins was also discovered here.

Fig. 1. Stupné-Žeravica. View of the site from the east.

Fig. 2. Stupné-Žeravica. Map of the hillfort with indicated two terraces in the northern part of the area and fortification on the top. The numbered spots indicated locations of hoards (larger marks) and important finds near the fortification. Point (GPS) 810 - iron belt hood; 813 - zoomorphic pendant; 814 - coin of Zemplín type; 815 - hoard 1; 816 - hoard 2; 818 - coin of Nitra type, 820-822 - coin of Divinka type.

Fig. 3. Stupné-Žeravica. 1-4 - coins discovered on the slopes of the hill; 5-Hoard 1 (according to Fröhlich 2016). 2-5 - no scale.

Fig. 4. Stupné-Žeravica. Fibulae from the hillfort and the slopes below it. 1-5, 7-13-iron; 3, 8- bronze.

Fig. 5. Stupné-Žeravica. Ornaments and parts of belt. 1, 3-6-bronze; 2 - iron.

Fig. 6. Stupné-Žeravica. Iron artifacts.

Fig. 7. Stupné-Žeravica. Arrow points and spear head. Iron.

Fig. 8. Stupné-Žeravica. Fully metallic axe. Iron (accroding to Fröhlich 2016). No scale.

Fig. 9. Stupné-Žeravica. Fragment of a tin artifact with representation of a human face. No scale.

Fig. 10. Stupné-Žeravica. Earring. Bronze. No scale.

Fig. 11. Nimnica-Holíš. Part of a tin ring. No scale.

Fig. 12. Nimnica-Holíš. Fibulae. 1, 5, 8, 9 - iron; 2-4, 6, 7 - bronze.

Fig. 13. Nimnica-Holís. Finds from the hillfort. 1, 5, 6, 8, 9 - bronze; 2-4-bronze and enamel; 7, 10, 11 -iron.

Fig. 14. Nimnica-Holíš. Zoomorphic pendant. Bronze. No scale.

Mgr. Lucia Ježišková

Archeologický ústav SAV Nitra

Akademická 2

SK - 94921 Nitra

nrauljez@savba.sk
PhDr. Karol Pieta, DrSc.

Archeologický ústav SAV Nitra

Akademická 2

SK - 94921 Nitra

nraupiet@savba.sk 